\title{
Conservation Effort of Natural Enemies Animal by Creating The Green Park and Play Ground in Malang
}

\author{
Lubna Ahmed Abo Al-Qassem Shahub ${ }^{1}$, Bagyo Yanuwiadi², Zaenal Fanani ${ }^{3}$, \\ ${ }^{1}$ Master Program of Environment Resources Management, Graduate Program, University of Brawijaya, Malang, \\ Indonesia \\ ${ }^{2}$ Faculty of Animal Husbandry, University of Brawijaya, Malang, Indonesia \\ ${ }^{3}$ Department of Biology, Faculty of Mathematics and Natural Sciences, University of Brawijaya, Malang, Indonesia
}

\begin{abstract}
The play grounds and green parks in Malang was developed until nowadays in the effort of enhancement the environment in Malang. With improving of the quality of services of that public area, it will increase the achievement of visitor satisfaction and their perception about its function. The research was conducted to evaluate the existing condition in Malang City Park, to analyze the perception of the visitors to the utilization play grounds in the city and to formulate the recommendations in improving the play ground for the conservation of natural enemies. For these purposes, questionnaires were developed and it was interviewed to the visitors of the play ground as respondents. Data collected were analyzed using Gap Analysis compared to the ideal of green park as play ground according to the governance criteria. Based on research results, most of the visitors were satisfy with the play ground, but their perception to its function were no so clear. By implementing some suggestion of the stakeholders (University and NonGovernmental Organization) almost all of the criteria of ideal green open space were already similar with its from the government. The improvement in the educational characters of the play ground and be considered for the ideal multifunction play ground in Malang City.
\end{abstract}

Keywords: Multi function, Play ground, Visitor perception

\section{INTRODUCTION}

In the Law of the Republic of Indonesia Number 26 Year 2007 About Spatial mentioned that the city spatial planning must be added the plan Provision and utilization of green open space (GOS), the type and percentage of green space where it spread, consisting of GOS public and private green space. It was also mentioned in this article that, the proportion of green open space of at least 30 percent of the area of the city, the proportion of public green open space in the city area of at least 20 percent of the total area of the city. Distribution of public green open space must be considered to the population distribution and service hierarchy by observing the plan structure and spatial patterns. Thus, with this regulation, any issues concerning with public services, become very important, in addition to environmental issues.

In order to provide public services, Malang government added the function of GOS was also functioned as a playground. Of course, this very friendly action was concerned with public policy

Correspondence address:

Lubna Ahmed Abo Al-Qassem Shahub

Email : lash772002@yahoo.com

Address : Master Program of Environment Resources

Management, University of Brawijaya analysis. The needs to the public space was taken into account to be very serious needs. In the procurement of public spaces, the government meets the minimum service standard of public works and spatially based on the Regulation of the Minister of Public Works No. 14 / PRT / M / 2010.

The facts showed that creating green open spaces in urban areas is very difficult, because of the conversion of open land into smaller plots with its new function and also from the public refusing. The existing GOS in Malang is part of the open spaces in the urban area that is filled with herbs, plants and vegetation (endemic, introduction) to support benefit directly and or indirectly. It included safety, comfort, welfare, and the beauty of the urban area [1]. As well as the Public Park of big cities, it is also equipped with a jogging track, pedestrian area, sitting banks, children's play parks, water parks, as well as the parking area.

Public space is a space that serves to activities related to community interaction, increased revenue, art performances [2]. Attractive public space will always be visited by the public with different levels of social, economic, ethnic, educational level, age differences, and different motivations or interests [2]. Among the public spaces visited by people of the town is the park downtown. The 
park is usually located in the downtown area, in the form of a green field with trees shade surround, or in the form of urban forest with traditional patterns or it can be the designer of new development form [2]. The public spaces are equipped with the activities infrastructure of the community to interact, increasing the quality of health care, increase revenue, and performing arts.

It's just a beautiful idea if green parks and playgrounds can be created without damaging the environment. This was the main thing that inspires to conduct the research in Malang.

\section{Research Purposes}

These are the purposes of the research:

1. To evaluate the existing condition in Malang City Park

2. To analyze the perception of the visitors to the utilization playgrounds in the city

3. To formulate the recommendations in improving the playground for the conservation of natural enemies

\section{Benefits Research}

This study will have the benefit of academic and practical.

The result of the research was firstly directed to enrich students in the application of the ecological concepts for environmental conservation. Secondly, the result was wanted to get the knowledge of the perception of visitors about the utilization of the playground. For the practical needs, the result can be used as direct activities planning concerning the management of playground that can be functioned as natural enemies sites.

\section{MATERIAL AND METHOD}

To achieve the aim of the research, we conducted a qualitative gap analysis comparing information between the gardens in Malang and global standards, and we collect Data from questionnaires that have been distributed to the public of three parks located in Malang, namely Alun - Alun Malang, Malang town square intelligent Parks Malang, a number of 60 respondents

\section{Data Collection}

Types of data according to its nature

According to its data in this study can be divided into two general categories:

1.Quantitative data

The quantitative data collected in this study is the Garden Malang, the distribution of by demographic variables, the distribution of respondents by the variable intensity of use of the serviceparkMalang.

2.QualitativeData

The qualitative data collected in this study are the data history of the company, data is a competitor, respondents' perceptions of each statement on the questionnaireatMalangState Parks.

3.Types of data from source

According tothe sourcedata usedin this study canbe dividedinto two, namely:

a) Primary Data

Primary data are data that comes directly from the source data collected specifically and directly related to the problems studied. The primary data required in this study are the data obtained from the respondents' answers to a series of questions specifically related to visitor satisfaction and service quality recommendation. b) Secondary data

Secondary data is data obtained directly by researchers but derived from data held by the company, the study of literature, literature, previous research journals and magazines related to the problems being studied. Secondary data in this study include history and data from the public in Malang City Park.

4.Population and Sample

The population in this study is all consumers / people who've come to the unfortunate city park. The sampling technique used in this study is a non-probability sampling technique, where the total population is unknown. Respondents were determined using purposive sampling technique. Purposive sampling is a sampling technique to take samples that are based on certain considerations. In the GAP analysis, appropriate sample size is between 100-200. In this study, the sample size isdetermined on the basis of the number of statements contained in the questionnaire. The sample size is $5-10$ times the number of grains statement. Because the number of parameters in this study was 25 grain size will be between 125-250 samples. However, pursuant considerations of practicality and costs, the size of the sample, determined as many as 130 people. Consideration used in selecting respondents (purposively sampling), is based on the following conditions:

1. The park service users Malang minimal never once came to the Garden City of Malang. It is obtained through the data people who've come to Malang City Park.

2. Malang State Parks service users are being viewed by those closest to you can be found 
and were able to fill out a questionnaire given.

\section{RESULT AND DISCUSSION}

Characteristics of respondents State Parks Malang

Data were obtained from questionnaires that have been distributed to the public of three parks located in Malang, namely Alun - Alun Malang, Malang town square and intelligent Parks Malang, a number of 60 respondents. Based on these data, Acquired the characteristics of the respondent as presented in table 5.1.

Table 5.1 Distribution of Respondents According to Demographic Variables

\begin{tabular}{|c|c|c|c|}
\hline VARIABLE & IDENTIFICATION & $\begin{array}{l}\text { TOTAL } \\
\text { PEOPLE }\end{array}$ & $\begin{array}{l}\text { PRESENTATION } \\
\text { (\%) }\end{array}$ \\
\hline \multirow[t]{5}{*}{ AGE } & $<16$ & 9 & 15 \\
\hline & $17-26$ & 25 & 41.67 \\
\hline & $27-36$ & 17 & 28.33 \\
\hline & $>36$ & 9 & 15 \\
\hline & TOTAL & 60 & 100 \\
\hline \multirow[t]{5}{*}{ WORK } & $\begin{array}{l}\text { GOVERNMENT } \\
\text { EMPLOYEES }\end{array}$ & 3 & 5 \\
\hline & ARMY & 3 & 5 \\
\hline & PRIVATE & 15 & 25 \\
\hline & ETC & 39 & 65 \\
\hline & TOTAL & 60 & 100 \\
\hline \multirow[t]{5}{*}{ EDUCATION } & $\begin{array}{l}\text { JUNIOR HIGH } \\
\text { SCHOOL }\end{array}$ & 15 & 25 \\
\hline & $\begin{array}{l}\text { SENIOR HIGH } \\
\text { SCHOOL }\end{array}$ & 26 & 43.33 \\
\hline & BACHELOR & 13 & 21.67 \\
\hline & ETC & 6 & 10 \\
\hline & TOTAL & 60 & 100 \\
\hline \multirow[t]{4}{*}{ FOUR } & $\begin{array}{l}\text { ALUN ALUN } \\
\text { MALANG }\end{array}$ & 19 & 31.67 \\
\hline & $\begin{array}{l}\text { ALUN ALUN } \\
\text { TUGU MALANG }\end{array}$ & 26 & 43.33 \\
\hline & $\begin{array}{l}\text { TAMAN CERDAS } \\
\text { TRUNOJOYO }\end{array}$ & 15 & 25 \\
\hline & TOTAL & 60 & 100 \\
\hline
\end{tabular}

Based on Table 5.1 it can be seen that the age group 17-26 years .

Dose the age group most wear visit Taman Malang with a percentage of 41.67 percent. Judging from the type of work, it is known that other work other frequently visited Park City Malang with a percentage of 65.00 percent. Judging from the level of education can be seen that the level of high school education at the most with a percentage of 43.33 percent, while the number of people who frequently visit with
Park City Malang is Alun - Alun Tugu Malang with a percentage of 43.33 percent.

\section{Reasons visitor go to the playground}

1. playgrounds is good for Physical activity and essential part of an individual's efforts to stay healthy, fight obesity and prevent chronic conditions that lead to coronary disease, high blood pressure and diabetes.

2. Parks have true economic benefits.

3. Parks preserve critical wildlife habitat. but few people know about the types of plants and animals and the importance of parks to preserve them

4. Parks and recreation facilitate social interactions that are critical to maintaining community cohesion and pride.

5. Leisure activities in parks improve moods, reduce stress and enhance a sense of wellness.

6. Recreational programs provide organized, structured, enjoyable activities for all ages.

7. Community recreation services provide a refuge of safety for at-risk youth Especially teenagers

\section{GAP ANALYSIS}

1. Function of hydrology, ecology, health, aesthetic

Standard:

For hydrology is ground to absorb water and Reduce the potential for flooding. Ecology is the existing trees around the garden it is able to maintain the balance of ecology, with preserving biodiversity, as the city's air filter gas pollution, dust, gas fastener and carbon various microclimate regulators. For we know that the health of the human body in order Ranging remain at $37^{\circ} \mathrm{C}$, around a garden filled with With trees and flowers pretty capable Being lungs - pulmonary city suck $\mathrm{CO} 2$ and replace With $\mathrm{O} 2$ very fresh when in inhaled. Trees - trees in a city park can also provide benefits of beauty, an antidote to the wind and the light filter sun. To form a city park aesthetics and image building a city that can serve as a means of cultural development, education and activity center community.

As a recreational area as a place to spend the restThe time to enjoy the beauty of the city it is not wronglf the end just sit - sit back, trot. Garden city as well as a container that houses a variety ofThe interaction of social, economic, and cultural. 


\section{Malang Park:}

In terms of hydrology, ecology, health esthetics and recreation Malang has shown according to the standard conditions normal or expected for local community's views of the research we see that the Square is a monument Malang really be a priority.

The GAP between them:

A dish that is already in view of the expected variable corresponding public concern about the environment Malang city park views from respondents showed concern that has been conducted by researchers.

\section{Ecological functions}

Standard:

Future technology should function primarily in bioregional pattern and scale. Communities must maintain the biodiversity and environmental integrity of design and construction that reflects the condition bioregional and reduce the impact of use on humans.Commission environment and sustainable development as a fulfillment of the needs of the present without compromise ability of future generations.

Malang Park:

Seen from the city of Malang is the ongoing impact needs to be aware of the conditions around the Malang city park, but did not rule out the development for more.

The GAP between them:

Concerned about the impacts that will come already become the majority of people on the environment

\section{Trees release oxygen}

\section{Standard:}

Has a very important role in the circulation of air that was in the Garden, where plants through the process of photosynthesis transform $\mathrm{CO} 2$ into 02. The Earth's changing environment proved to air gets hot, especially when the sun rises, which at the time was no longer the morning air is fresh, felt only the heat. Air pollution also has been performed, it will directly affect air quality is getting worse

\section{Malang Parks:}

Concerning the Malang city park tree to represent the continuity of the air in the review with poor air cooled.To standard trees already meet what is expected.

\section{The GAP between them}

Assessment of the garden city of Malang to environmental standards into the quality of the environment, including air pollution now beginning where is where, with Gap analysis is expected will provide further development of the impact on the surrounding environment

\section{Water Purification}

Standard:

Clear, colorless, tasteless taste, no smell, a normal and does not contain solids. Clean water is essential for human life, it is necessary to know the requirements of clean water can be in the know obout the physical, chemical and biological. Physical quality: good flavor and color to be reviewed Chemical quality: observation of hardness, $\mathrm{pH}$ ion content and so on.

\section{Malang Parks:}

In terms of flavor and clearly still are lacking for an ornament, but in terms of the children's playground was appropriate standard

\section{The GAP between them:}

Responsive to public complaints conveyed to changes in water content so that comfortfor children are protected, thereby reducing the frustration of the people who were there.

\section{Human Health}

\section{Standard:}

The park is filled with trees as the lungs, heart of the city is producer oxygen is not replaced and is in need for the health of the surrounding community. all that is in the city park can be used and enjoyed by all levels of society. The park is the city that is in place strategy, easily accessible to all the people, both small children, teenage parents, rich or poor.

\section{Malang parks:}

Everything is meet for park Malang and unbelievably giving importancecommunity culture to health.

\section{The gap between them:}

The response to the public health give positive value to the garden city of Malang, which can provide information on the health cult.

\section{Garden design}

Standard:

Garden design should be built in a city is at 7 to $11.5 \mathrm{~m} 2$ per person there is also based on the breadth and range of places to stay.

Malang Parks:

Malang has little effect good design and everything is very close to people's residences as well as the close of worship and another one close to offices and shopping centers.

The GAP between them:

Means of support with a design that is expected to Culture Malang give importance to the design 
values that provide comfort. Malang views from the City Park near the office, worship and shopping centers.

\section{Safety playground \\ Standard:}

Provides a sense of comfort, safe while in the playground so that it can improve child development to ensure the needs of children

Malang parks:

Seen in terms of safety for children is in conformity with the level of development, comfort, security and emotional child.

\section{The GAP between them:}

Emotionally that it gives a sense of security and will have the protection of a place that serves the entertainment of children should pay special attention.

Values expect protection in the unfortunate State Parks must pay attention to quality attributes tools or garden tools Malang.

\section{Trees in the garden thorny}

Standard:

Single-stemmed plants need hardwood tree, the tree has a height of up to 7 meters, 7-12 meters for medium and large trees trees more than 12 meters.

\section{Malang park:}

Malang weather was very cool with the tree adds to the atmosphere coupled with the beauty of flowers diverse, manicured lawns provide shade atmosphere.

\section{The GAP between them:}

Attention respondents to the number of trees, flowers give very satisfying with the garden city of Malang. Is expected to give a level of satisfaction is a function of the differences in the hope that will come.

\section{Should not have beast in the park}

\section{Standard:}

Do not put the beast or harmful to people and their surroundings.

\section{Malang park:}

To the unfortunate beast, but not put in the garden city of Malang is a dove, butterfly Thusand fish in the pond so that adds to the beauty.

The GAP between them:

With the odd animals were very friendly is the ability to provide personalized attention to the community.

\section{The library space Visitor}

\section{Standard:}

Their library adds insight to the visitors, while the library is available books that are beneficial to the end and in the hope of children - like all children. The book - a book that contains knowledge, unfortunate circumstances, national culture which is very valuable for the visitors and the surrounding community. A cozy lounge, a comfortable seating will provide a sense of the Desire culture of reading.

Malang Park:

A culture of reading in Malang so high that the presence of a library in the park itself intelligently assigns values that can benefit the surrounding community.

\section{The GAP between them:}

The availability of supporting facilities such as libraries give a positive response to the respondent city of Malang. With the addition of new books will improve the reading culture in the community. The level of people's satisfaction Malang City park has been received and can be measured by comparing each variable level of service to the emotional assessment.

The satisfaction score is a concept to integrate and facilitate the public in choosing Parks in Malang.The dynamics of rapid developments in the area of the park is essential for maintaining the beauty of the park in Malang, where each garden has its own characteristics which can provide an icon for the city of Malang. Efforts to satisfying end in a way that is responsible and acceptable to all sections of society.

\section{Recommendations}

A. For entertain:

1. Landscaping and Planting Good use of landscaping and planting can greatly add to the attractiveness and play value of a playground.

2. Surfacing of playground, There are four types of surfacing:

- Loose fill materials such as wood chip and pallets, sand, pea gravel, and rubber

- Rubber surfaces

- Grass Mat is mesh rubber surface

- Carpet surfaces

\section{Centre of Community}

Playground space for kids to entertain with each other and meet new people. They're also great spaces for events and for people to engage in recreational activities. This allows people to develop a sense of community. A park is perfect 
for a picnic, a concert, its important for our community needs.

\section{B. For Education}

1. Make some booklet about the plant: example (Beneficial and detrimental species of plants ) Weeds are plants growing where they aren't wanted, and they aren't just sour sobs and thistles, Some plants escape from gardens and become serious environmental weeds which pouse a major threat to the health and value of our natural environments.

2. Make some booklet about the animals

3. A sign explaining the types of plants and the benefits of natural animals

\section{For supporting natural enemies habitat}

The playground is habitats of natural vegetation protect and enhance specific natural enemies and provide them with resources such as nectar, pollen, physical refuge, alternative prey, alternative hosts and mating sites. In order to reduce the pesticide-induced mortality of natural enemies and to improve natural enemy fitness and effectiveness. Such parks may play an important role in maintaining the biodiversity of natural enemies and enhancing natural pest control.

\section{D. for modren playground}

1. The proposed project is in a developed in a developed urban environment therefore it will not affect any current fish or wildlife habitat.

2. There will be change the diversity or abundance of animals or bird species.

3. must will not a barrier to the migration or movement of animals

4. prevention no adverse effect to threatened or endangered species or their habitat.

5. The exportation of new species.

6. recommendations by improving the quality of experience for those visiting the park.

7. Learning where the visitors experience involves understanding the animals and plants

Wildlife conservation and the preservation of biodiversity are our goals - create a world where more will be inspired to learn, appreciate and respect the animals, with whom we share our planet.

\section{CONCLUSION}

Finally to create a garden habitat that will be colonized naturally. claim to encourage beneficial insect residence in playground and diversity of flowering plants, There is a good species of plants and natural enemies in Malang city playgrounds. By being a good host to beneficial insects, spiders, and mites, your diversified, native plant-based garden should rarely experience plant pest outbreaks.

As a fully-functioning ecosystem, with a diverse and balanced biological community, it will be as attractive. And need to improving the quality of experience for those visiting the park by using the booklet about natural enemies animals and plants.

\section{REFERENCES}

[1]. Sukawan AM., 2012. Kajian Lapangan Ngurah Rai Sebagai Taman Kota Di Kota Singaraja. Tesis Program Magister Prograam Studi Arsitektur Program Pascasarjana Universitas Udayana.

[2]. Darmawan, E. 2009. Ruang Publik Dalam Arsitektur Kota. Semarang: Badan Penerbit Universitas Diponogoro.

[3]. Babin, Barry J, Yong-Ki Lee, Eun-Ju Kim, Mitch Griffin. 2005. Modeling Consumer Satisfaction and Word- of- Mouth : Restaurant Patronage in Korea. Journal of Services Marketing, 19, pp. 133-139.

[4]. Ferdinand, Augusty. 2002. Structural Equation Modelling Dalam Penelitian Manajemen. Aplikasi Model- model Rumit Dalam Penelitian Untuk Tesis Magister \& Disertasi Doktor. Semarang : BP UNDIP.

[5]. Ghozali, Imam. 2005.Model Persamaan Struktural, Konsep dan Aplikasi Dengan Program AMOS Ver. 5.0.Edisi II. Semarang : Badan Penerbit Universitas Diponegoro.

[6]. Michael Allaby, Diclionary the Eviroment, The Mac Million Press, Lth, London, 1979

[7]. Nommy Horas Thobing Sihaan Indonesia , Hukum Lingkungan Dan Ekologi Pembangunan

[8]. Otto Soemarwoto, Analisis Mengenal Dampak Lingkungkungan, Gahjah Mada ,University Press 2001

[9]. Parasuraman, A., V.A. Zeithaml, and L.L. Berry (1985), A Multiple-Item Scale for Measuring Consumer Perceptions of Service Quality. Journal of Retailing. Vol.64. No 1. pp. 12-40.

[10]. Prof Dr,H, imam Supandi, dr,Sp, Mk Lingkungan Hidup dan Kelestarian.

[11]. Santoso, Singgih. 2007. Struktural Equation Model Konsep dan Aplikasi Dengan AMOS. Jakarta. PT Elex Media Komputindo. 